\title{
Metadiscourse in Academic Writing: An Investigation of Saudi EFL Students' Research Articles
}

\author{
Majdah Alkhathlan \\ Independent Scholar, Saudi Arabia \\ Received August 17, 2019; Revised September 16, 2019; Accepted September 23, 2019
}

Copyright $\odot 2019$ by authors, all rights reserved. Authors agree that this article remains permanently open access under the terms of the Creative Commons Attribution License 4.0 International License

\begin{abstract}
This study investigated the type and frequency of metadiscourse markers used in fifty research articles written by Saudi EFL college students. In analyzing the data, Hyland's (2005) model of metadiscourse was adopted. The findings showed that there are significant differences in the frequency of interactive and interactional metadiscourse. The students employed more interactive metadiscourse markers than interactional ones. The analysis further revealed that transitions occurred most often in the research articles, followed by hedges. The least used metadiscourse markers were endophoric markers and attitude markers. To conclude, some pedagogical implications for teaching English writing to Saudi EFL college students were drawn from these findings. It can be noted that Saudi EFL college students need more training in using interactional metadiscourse to be able to convince the reader of their ideas and arguments in a text. In addition, they must be more aware of the importance of using metadiscourse in improving their writing skills in general.
\end{abstract}

Keywords Metadiscourse, Research Articles, EFL Learners, Interactional Metadiscourse, Interactive Metadiscourse

\section{Introduction}

In recent years, an increasing number of studies have been carried out to investigate the common problems faced by Second Language (L2) learners in English writing and their use of metadiscourse markers. The term metadiscourse was first formulated by the linguist Zellig Harris (1959) to refer to the way a writer or a speaker endeavors to guide a recipient's perception of a text (Hyland, 2005). It has been defined differently by various researchers. Crismore, Markkanen and Steffensen (1993), as an example, defines metadiscourse as "linguistic material in spoken or written texts, which does not add anything to the propositional content but that is intended to help the listener or reader organize, interpret, and evaluate the information given." (p. 40). Metadiscourse assists the writer (or speaker) to express a viewpoint clearly and engage effectively with readers as members of a certain community (Hyland, 2005). It also allows writers to change the subject, come to a conclusion, point out an important idea, define a term and acknowledge a difficult line of thought (Crismore, 1983).

The amount and type of metadiscourse markers needed in a text vary depending on the complexity of the text and its genre. For instance, Hyland (2005) developed a metadiscourse model for analyzing metadiscourse markers in English academic writing, where complex terms and arguments need to be made understandable and where social relations should be built and negotiated (Hyland, 2005). In his model, metadiscourse markers were divided into two main categories: interactive and interactional. Interactive metadiscourse markers help writers organize their ideas in a text, whereas interactional metadiscourse markers allow them to engage the reader in the text (Hyland, 2005).

Most studies interested in L2 learners' academic written discourse have found that L2 learners tend to use more interactive (textual) metadiscourse than interactional (interpersonal) metadiscourse in essay writing (Ali, 2016; Anwardeen, Luyee, Gabriel \& Kalajahi, 2013; Cubukcu, 2017; Mohamed \& Rashid, 2017; Pasaribu, 2017; Xu, 2001; Zakaria \& Malik, 2018). However, further studies seem to be needed to investigate the use of interactive and interactional metadiscourse markers by L2 learners in the genre of research articles. As such, this study set out to investigate the type and frequency of metadiscourse markers used in research articles written by learners of English as a Foreign Language (EFL) in the Saudi context. The findings of this study would have important implications for teaching English academic writing since metadiscourse is rarely taught explicitly in foreign language classrooms (Hyland, 2005). As argued by 
Thompson (2001), the training of novice writers needs to focus on both interactive and interactional metadiscourse.

\section{Literature Review}

While the practice of writing in general can serve different purposes, academic writing aims at documenting and imparting knowledge in a written form (Monippally \& Pawar, 2008). Traditionally, academic writing has been perceived as impersonal and objective rather than a subjective form of discourse, because it involves demonstration of the truth that is absolute and depends upon empirical evidence or flawless kind of logic. However, academic writing nowadays is viewed as a persuasive attempt entailing a social interaction between writers and their target readers (Hyland, 2005).

In academic writing, research articles are considered a challenging genre, both culturally and rhetorically for L2 writers, who may lack cultural awareness and the needed linguistic sophistication (Aijmer, 2002; Bliss, 2001; Park, 1986, as cited in Anwardeen et al., 2013). Additionally, Jiang (2011) claims that the challenges in L2 academic writing have roots not only in the linguistic realm, but also in the differences in values, philosophies, rhetorical strategies as well as audience awareness derived from cultures. Hence, L2 learners need to use appropriate metadiscourse markers within their written discourse in order to make their writing comprehensible (Zakaria \& Malik, 2018).

Metadiscourse markers are used by writers to organize their texts, engage their potential readers and signal their attitudes towards the text and their audience (Anwardeen et al., 2013). According to Lin (2005), there are several metadiscourse models that have been proposed by different scholars (e.g. Beauvais, 1989; Crismore et al., 1993; Vande Kopple, 1985; Williams, 1981, among many others). One of the recent metadiscourse models was suggested by Hyland (2005) (see Table 1)

As shown in Table 1, metadiscourse is divided into two major categories, namely: interactive and interactional resources. The interactive resources help writers construct and shape a text to meet the needs of their target readers, and they are subcategorized into transitions, frame markers, endophoric markers, evidentials, and code glosses. The interactional resources allow writers to express their views explicitly, engage with their readers by responding to an imagined dialogue with them. Interactional metadiscourse markers include hedges, boosters, attitude markers, self-mentions, and engagement markers. (Hyland, 2005).

There exists a considerable body of literature on metadiscourse in L2 learners' academic writings. One of the earliest works on metadiscourse was carried out by Intaraprawat and Steffensen (1995). They explored the use of different types of metadiscourse markers in persuasive essays written by English as a Second Language (ESL) undergraduate writers, and they found that the essays that received good ratings by the researchers employed different varieties of metadiscourse markers than did the ones which received poor ratings. Simin and Tavangar (2009) argue that "the more proficient learners are in a second language, the more they use metadiscourse markers in their writings" (p. 241).

Table 1. Hyland's Interpersonal Model of Metadiscourse (2005, p. 49)

\begin{tabular}{|c|c|c|}
\hline Category & Function & Examples \\
\hline Interactive & $\begin{array}{l}\text { Help to guide the } \\
\text { reader through the } \\
\text { text. }\end{array}$ & Resources \\
\hline Transitions & $\begin{array}{l}\text { express relations } \\
\text { between main } \\
\text { clauses }\end{array}$ & $\begin{array}{l}\text { In addition; but; thus; } \\
\text { and }\end{array}$ \\
\hline Frame markers & $\begin{array}{c}\text { refer to discourse } \\
\text { acts, sequences or } \\
\text { stages }\end{array}$ & $\begin{array}{l}\text { finally; to conclude; } \\
\text { my purpose is }\end{array}$ \\
\hline $\begin{array}{l}\text { Endophoric } \\
\text { markers }\end{array}$ & $\begin{array}{l}\text { refer to information } \\
\text { in other parts of the } \\
\text { text }\end{array}$ & $\begin{array}{l}\text { noted above; see } \\
\text { figure; in section } 2\end{array}$ \\
\hline Evidentials & $\begin{array}{l}\text { refer to information } \\
\text { from other texts }\end{array}$ & $\begin{array}{c}\text { texts according to } \mathrm{X} ; \\
\mathrm{Z} \text { states }\end{array}$ \\
\hline Code glosses & $\begin{array}{c}\text { elaborate } \\
\text { propositional } \\
\text { meaning }\end{array}$ & $\begin{array}{l}\text { namely; e.g.; such as; } \\
\text { in other words }\end{array}$ \\
\hline Interactional & $\begin{array}{l}\text { Involve the reader in } \\
\text { the text }\end{array}$ & Resources \\
\hline Hedges & $\begin{array}{c}\text { withhold } \\
\text { commitment and } \\
\text { open dialogue }\end{array}$ & $\begin{array}{l}\text { might; perhaps; } \\
\text { possible; about }\end{array}$ \\
\hline Boosters & $\begin{array}{l}\text { emphasize certainty } \\
\text { and close dialogue }\end{array}$ & $\begin{array}{l}\text { In fact; definitely; it is } \\
\text { clear that }\end{array}$ \\
\hline $\begin{array}{l}\text { Attitude } \\
\text { markers }\end{array}$ & $\begin{array}{c}\text { expresses writers' } \\
\text { attitude to } \\
\text { proposition }\end{array}$ & $\begin{array}{l}\text { unfortunately; I agree; } \\
\text { surprisingly }\end{array}$ \\
\hline Self-mentions & $\begin{array}{l}\text { explicit reference to } \\
\text { author(s) }\end{array}$ & I; we; my; me; our \\
\hline $\begin{array}{l}\text { Engagement } \\
\text { markers }\end{array}$ & $\begin{array}{l}\text { explicitly build } \\
\text { relationship with } \\
\text { reader }\end{array}$ & $\begin{array}{l}\text { consider; note; you } \\
\text { can see that }\end{array}$ \\
\hline
\end{tabular}

In general, several studies have found that L2 writers tend to employ a higher number of interactive (textual) metadiscourse markers in their academic writing than interactional (interpersonal) metadiscourse markers. For example, the study conducted by Mohamed and Rashid (2017) on the use of metadiscourse by Malaysian ESL undergraduate students in their short persuasive essays showed that undergraduates used more interactive metadiscourse markers than interactional once, because the use of interactional metadiscourse requires writers to have a strong command of their writing skills. The results of the study also revealed that transitions were the most used metadiscourse markers by ESL learners, while evidentials were the least used metadiscourse markers and that is because citation is not often used in this type of essays.

A similar conclusion was reached by Zakaria and Malik (2018) who conducted a study to investigate the use of metadiscourse by ESL Arab pre-university students in 
opinion-based essays. They found that the students employed more interactive metadiscourse markers than interactional ones. Their study also showed that the most used type of metadiscourse markers was transitions, and the least used type of metadiscourse markers was endophoric markers.

Contrary to what have been found in previous studies on L2 writers, the study conducted by Heng and Tan (2010) revealed that the corpus of argumentative essays written by Malaysian undergraduate students exhibited more interactional metadiscourse markers rather than interactive metadiscourse markers. Similar to Heng and Tan's (2010) findings mentioned above, Mahmood, Javaid and Mahmood (2017) found that Pakistani undergraduate students were more inclined to using interactional metadiscourse markers instead of interactive ones in their argumentative essays. Nevertheless, in both studies, 'transitions' which is one of the subcategories of interactive metadiscourse, was the most frequently used type of metadiscourse by L2 learners. It can be concluded from the literature review that is in order for L2 learners to have a strong command of their writing skills and deliver their ideas successfully, it is essential that they employ different varieties of metadiscourse in their academic written discourse.

\section{Methodology}

\subsection{Data Collection}

To investigate the use of metadiscourse by Saudi EFL college students, a total of fifty research articles within the fields of translation and interpretation were randomly selected from an online magazine called KSU- COLT's RAIT (Research Articles in Interpretation and Translation) (Al-Sibai, 2017). KSU- COLT's RAIT is a collection of research articles written in English by EFL level-six college students who are majoring in English-Arabic translation at King Saud University (KSU) (Al-Sibai, 2017). The EFL writers speak Arabic as their first language, and they all had passed different courses pertaining to writing research articles, for example, Vocabulary Building; Grammar 1, 2, and 3; Writing 1 and 2; and Essay and Summary Writing. Hence, it is presumed that the students have knowledge of standard English writing conventions, for example, sentence structure types.

The research articles found in the magazine were compiled by an instructor at $\mathrm{KSU}$, as part of a research methodology course requirement which entails that each student writes a research article. All the research articles written by the students were included in the KSU-COLT's RAIT magazine with no exception (Al-Sibai, 2017). The course instructor's interference in the research articles is minimal since she was supervising about 50 students' research articles in each semester, in addition to giving lectures and exams. The structure of the research articles consisted of three parts: introduction, body paragraphs and conclusion. All selected research articles for analysis were approximately similar in word count as shown in Table 2.

Table 2. Size of the Corpus

\begin{tabular}{|c|c|c|}
\hline No. of articles & $\begin{array}{c}\text { AVG No. of words per } \\
\text { article }\end{array}$ & No. of tokens \\
\hline 50 & 520 & 23870 \\
\hline
\end{tabular}

\subsection{Procedure}

In the present study, the metadiscourse model suggested by Hyland (2005) was adopted to investigate the deployment of metadiscourse markers in research articles for several reasons. First, his model was noted to be more relevant to academic written discourse than other models (Kitjaroenpaiboon \& Getkham, 2015). Second, it provides better comprehensibility of metadiscourse resources and distinction to its varieties (Anwardeen, et al., 2013). Third, it is considered as an open and evolving model in that any study on metadiscourse can contribute to the building up of metadiscourse items in the model (Heng \& Tan, 2010). Lastly, it is more frequently used in previous studies since it is an update of previous models of metadiscourse.

The analysis of the data was carried out electronically and then manually. First, the data were uploaded to AntConc software (Version 3.5.7), a free corpus analysis software that was developed by Anthony (2018), in order to analyze the frequency of metadiscourse usage by Saudi EFL learners in research articles based on the list of metadiscourse items compiled by Hyland (2005). Hyland's (2005) list consists of 498 possible metadiscourse items in academic writing. To make the analysis more accurate, the titles, references, and quotations were excluded from the analysis.

Next, each item was carefully analyzed manually since it can either represent the propositional discourse or metadiscourse depending on the context in which it occurs (Hyland, 2005). Then, the items were classified into the subcategories of either interactive (code glosses, transitions, endophorics, frame markers or evidentials) or interactional metadiscourse (self-mentions, booster, attitude markers, engagement markers, or hedges). After classifying the metadiscourse items and calculating their frequencies, Rayson's (2008) Log Likelihood Calculator was used to find out whether the differences in total use of interactive and interactional metadiscourse are significant or not.

\section{Results}

As mentioned earlier, the present study attempts to perform a textual analysis of metadiscourse markers in research articles written by Saudi EFL college students. The textual analysis of the total corpus has shown that all types of metadiscourse markers were present in the 
research articles written by Saudi EFL college students. There were 3.409 metadiscourse items in 23.870 words, in 50 research articles. That is, there was approximately one metadiscourse item in each 7 words.

Table 3. Main Results of the Textual Analysis

\begin{tabular}{|c|c|c|}
\hline Main Category & Frequency & Percentage \\
\hline Interactive markers & 2139 & $8.961 \%$ \\
\hline Interactional markers & 1270 & $5.320 \%$ \\
\hline
\end{tabular}

As shown above, the total number of interactive metadiscourse markers is $2139(8.961 \%)$, whereas the total number of interactional metadiscourse markers is 1.270 (5.320\%). The result of the Log Likelihood (LL) test for statistical significance is $L L=223.98$, and this shows that there is a highly significant difference between the frequencies of interactive metadiscourse markers and interactional once $(p<0.0001)$. Saudi EFL college students have employed more interactive metadiscourse markers than interactional ones. For more in-depth analysis, the subcategories of both interactive and interactional metadiscourse were examined (see Table $4 \&$ Table 5).

Table 4. Frequency of Interactive Resources in the Corpus

\begin{tabular}{|c|c|c|}
\hline Interactive Resources & Frequency & Percentage \\
\hline Endophoric markers & 58 & $2.711 \%$ \\
\hline Evidentials & 299 & $13.97 \%$ \\
\hline Code glosses & 279 & $13.04 \%$ \\
\hline Frame markers & 171 & $7.994 \%$ \\
\hline Transition markers & 1332 & $62.27 \%$ \\
\hline Total & 2139 & $100 \%$ \\
\hline
\end{tabular}

Table 4 shows that the most frequent subcategory of interactive metadiscourse employed by EFL college students was transitions which constituted $62.27 \%$ of all interactive metadiscourse markers. Among the remaining four subcategories of interactive metadiscourse, evidentials constituted $13.97 \%$, approximately the same as code glosses 13.04\%. Frame markers (7.994\%) and endophoric markers $(2.711 \%)$ were the least used subcategories of interactive metadiscourse.

Table 5. Frequency of Interactional Resources in the Corpus

\begin{tabular}{|c|c|c|}
\hline Interactional Resources & Frequency & Percentage \\
\hline Attitude markers & 97 & $7.63 \%$ \\
\hline Boosters & 251 & $19.76 \%$ \\
\hline Self-mention & 178 & $14.01 \%$ \\
\hline Engagement & 338 & $26.61 \%$ \\
\hline Hedges & 406 & $31.96 \%$ \\
\hline Total & 1270 & $100 \%$ \\
\hline
\end{tabular}

The analysis of the interactional metadiscourse markers in the corpus has revealed that hedges $(31.96 \%)$ were the most frequently used resource among interactional resources. It also has shown that engagement markers constituted (26.61\%), boosters (19.76\%) and self-mentions (14.01\%). Attitude markers (7.63\%) were the least used interactional metadiscourse markers in the research articles.

\section{Discussion}

This study set out with the aim of investigating the use of metadiscourse markers in research articles written by Saudi EFL learners. As expected based on previous studies, the analysis of the data showed that there was a statistically significant difference in the use of the two main categories of metadiscourse: interactive and interactional. That is, Saudi EFL learners were more inclined to using interactive metadiscourse instead of interactional metadiscourse. This implies that the students focused more on organizing the text rather than on involving the reader in the text. Perhaps that is because they did not receive explicit instruction on how to use interactional metadiscourse and its importance.

This result is in agreement with previous studies that showed that L2 learners tend to use more interactive metadiscourse markers than interactional once (Mohamed \& Rashid, 2017; Zakaria \& Malik, 2018). A number of plausible explanations for this result were provided in previous studies. For example, Zakaria and Malik (2018) relate the frequent use of interactive resources to cultural differences reflected in the students' writing conventions and styles. Another likely explanation is put forward by Mohamed and Rashid (2017), who attributed the frequent use of interactive metadiscourse to the notion that the use of effective interactional metadiscourse involves engaging the readers by drawing them into the discussion of the text and achieving this depends on the writing skills of the writer. To put it differently, experienced writers use more interactional metadiscourse resources than inexperienced writers.

Among the interactive resources, the results of this study have shown that transitions were the most used subcategory of metadiscourse by Saudi EFL college students. This result is in agreement with Zakaria and Malik's (2018) finding that transitions were the highest used metadiscourse markers among Arab English learners. It seems quite natural that transitions were frequently used by the students since they are the typical way of representing internal connections in the text (Hyland, 2005). The most frequent item of transitions is 'and' which appeared for about 761 times in the research articles. Evidentials and code glosses were the second and third most frequently seen categories of interactive metadiscourse. The frequent use of evidentials might be explained by the fact that writing a research paper requires citing related works in the literature to strengthen and support the arguments in the paper. The frequent use of 
code glosses suggests that the students were able to provide additional information, by explaining, rephrasing or elaborating what has been stated to ensure that the reader comprehends the writer's intended meaning (Hyland, 2005).

The frequency of frame markers was low in the corpus, and this might indicate that the students were not able to sequence, label parts of the text, predict and shift topics or arguments to make the text clear to its readers (Hyland, 2005). Endophoric markers were the most infrequent metadiscourse marker in the whole corpus. This might be due to the fact that the word count of the research articles is low (approximately 520 words), and endophoric markers are typically used to refer to other parts of the text such as sections or chapters (Hyland, 2005).

Within the interactional resources, the findings have shown that hedges were the second most common metadiscourse subcategory in the corpus. This may stem from the fact that hedges stress "the subjectivity of a position by allowing information to be presented as an opinion rather than a fact." (Hyland, 2005, p. 52). The most frequent word of this subcategory of interactional metadiscourse as observed in the corpus is the modal auxiliary verb 'should'. The frequent use of the modal auxiliary verb 'should' seems to suggest that the students used hedges not just to express their opinion but also to increase its force.

Engagement markers were also frequently used in the corpus, followed by boosters and self-mentions. The most common engagement marker in the corpus is 'you' which is typically used to include the reader in the text (Hyland, 2005). Different from engagement markers, boosters indicate certainty. The majority of boosters observed in the corpus were used to highlight the students' levels of confidence in the truth of propositions in the text (Hyland, 2005). The most used boosters by Saudi EFL learners were 'know' and 'in fact'.

Self-mentions were used in the corpus to signal the writers' presence in the text (Hyland, 2005). The most frequent self-mention used in the research articles is the inclusive pronoun 'we'. Surprisingly, attitude markers were the least used interactional metadiscourse in the corpus. Low frequency of attitude markers might indicate that the students were not very effective in explicitly expressing their attitudes toward propositional content (Hyland, 2005).

In summary, we can conclude that although the use of interactional metadiscourse is crucial in effectively engaging the reader with the message of the text (Hyland, 2005), Saudi EFL college students used more interactive metadiscourse markers in writing research articles than interactional metadiscourse markers. This finding suggests that Saudi EFL college students need more training in using interactional metadiscourse to be able to convince the reader of their arguments in the text. In addition, they must be more aware of the importance of using metadiscourse in improving their writing skills in general.

\section{Conclusions}

Based on Hyland's (2005) model of metadiscourse, the present study examined the use of metadiscourse in 50 research articles written by Saudi EFL college students. The results of the study showed that Saudi EFL college students employed interactive metadiscourse markers more than interactional metadiscourse markers. The in-depth analysis of the metadiscourse markers in the sample research articles revealed that transitions were the most frequent markers followed by hedges. In addition, endophoric markers and attitude markers were the least used metadiscourse markers in the whole corpus. These results emphasize the need for direct instruction of metadiscourse to Saudi EFL learners in order to improve their writing skills. Since the current study was restricted to Saudi EFL College students enrolled in a research methodology course, the results cannot be generalized beyond that particular group.

The present study has a number of limitations. One limitation of this study is that the total number of words in the corpus was relatively small. A study of a larger corpus of data is required to obtain more significant results. Another limitation is that the scope of the present study was limited only to metadiscourse usage in one genre which is research articles. Therefore, researchers are encouraged to investigate the use of metadiscourse among Saudi EFL learners in other genres (e.g., cause and effect essays), and see whether EFL learners use more interactive resources than interactional ones. In addition, it is recommended that future research compares the use of metadiscourse by Saudi EFL learners and their English language proficiency levels to investigate whether overuses or underuses of a certain metadiscourse category is related to language proficiency levels.

\section{REFERENCES}

[1] Ali, A. Q. (2016). Metadiscourse markers in advanced EFL learners' academic writing. Iraq Academic Scientific Journals, (9), 19-38.

[2] Al-Sibai, D. (2017). KSU - COLT's RAIT (Research Articles in Interpretation and Translation), (7), 215. Retrieved from https://fac.ksu.edu.sa/sites/default/files/rait journal_issue_6.pdf

[3] Anthony, L. (2018). AntConc (Version 3.5.7) [Computer Software]. Tokyo, Japan: Waseda University.

[4] Anwardeen, N., Luyee, E., Gabriel, J., \& Kalajahi, S. (2013). An analysis: The usage of metadiscourse in argumentative writing by Malaysian tertiary level of students. English Language Teaching, 6(9), 83-96. 
[5] Crismore, A. (1983). Metadiscourse: What it is and how it is used in school and non-school social science texts. Center for the Study of Reading (Vol. Technical Report No. 273): Urbana-Champaign University of Illinois.

[6] Crismore, A., Markkanen, R. \& Steffensen, M.S. (1993). Metadiscourse in persuasive writing: A study of texts written by American and Finnish university students. Written Communication, vol. 10, no.1, pp. 39-71.

[7] Cubukcu, F. (2017). Revisiting Metadiscourse Markers of the Language Learners in Academic Writing. Revista Romaneasca pentru Educatie Multidimensionala, 9(2), 36-47.

[8] Heng, C., \& Tan, H. (2010). Extracting and comparing the intricacies of metadiscourse of two written persuasive corpora. International Journal of Education and Development using Information and Communication Technology (IJEDICT), 6(3), 124-146.

[9] Hyland, K. (2005). Metadiscourse: Exploring interaction in writing. London: Continuum.

[10] Intaraprawat, P., \& Steffensen, M. (1995). The use of metadiscourse in good and poor ESL essays. Journal of Second Language Writing, 4(3), 253-272.

[11] Jiang, X. (2011). Challenges for college-level learners of academic English writing in China. In M. S. Plakhotnik, S. M. Nielsen, \& D. M. Pane (Eds.), Proceedings of the Tenth Annual College of Education \& GSN Research Conference (pp. 95-100). Miami: Florida International University.

[12] Kitjaroenpaiboon, W., \& Getkham, K. (2015). An analysis of interactional metadiscourse devices in communication arts research articles. International Journal of Management and Applied Science, 1(9), 125-131.

[13] Lin, C. (2005). Metadiscourse in academic writing: An investigation of graduate students' MA theses in Taiwan. Taiwan Journal of TESOL, 2(1), 1-66.

[14] Mahmood, R., Javaid, G., \& Mahmood, A. (2017). Analysis of metadiscourse features in argumentative writing by Pakistani undergraduate students. International Journal of English Linguistics, 7(6), 78-87.

[15] Mohamed, A., \& Ab Rashid, R. (2017). The metadiscourse markers in good undergraduate writers' essays corpus. International Journal of English Linguistics, 7(6), 213-220.

[16] Monippally, M. M., \& Pawar, B. S. (2008). Academic writing: A guide for management students and researchers. SAGE Publications India.

[17] Pasaribu, T. A. (2017). Gender differences and the use of metadiscourse markers in writing essays. International Journal of Humanity Studies, 1(1), 93-102.

[18] Rayson, P. (2008). Log-likelihood calculator. UCREL web server. Accessed on 22 March 2019 at: http://ucrel.lancs.ac .uk/llwizard.html

[19] Simin, S., \& Tavangar, M. (2009). Metadiscourse knowledge and use in Iranian EFL writing. Asian EFL Journal, 11(1), 230-255.

[20] Thompson, G. (2001). Interaction in academic writing: Learning to argue with the reader. Applied Linguistics,
22(1), 58-78.

[21] Xu, Haiming. (2001). Metadiscourse: A cross-cultural perspective. Nanjing: Southeast University Press.

[22] Zakaria, M. K., \& Malik, F. A. (2018). Metadiscourse in academic writing of pre-university Arab students at the International Islamic University Malaysia (IIUM). MATEC Web Conferences, 1-7. 